\title{
The World Trade Organization's Doha Cotton Initiative: A Tale of Two Issues
}

Kym Anderson and Ernesto Valenzuela

Development Research Group

World Bank, Washington DC

kanderson@worldbank.org

evalenzuela1@worldbank.org

World Bank Policy Research Working Paper 3918, May 2006

The Policy Research Working Paper Series disseminates the findings of work in progress to encourage the exchange of ideas about development issues. An objective of the series is to get the findings out quickly, even if the presentations are less than fully polished. The papers carry the names of the authors and should be cited accordingly. The findings, interpretations, and conclusions expressed in this paper are entirely those of the authors. They do not necessarily represent the view of the World Bank, its Executive Directors, or the countries they represent. Policy Research Working Papers are available online at http://econ.worldbank.org.

This is a product of the World Bank's projects on Agricultural Trade Reform and the Doha Development Agenda and Distortions to Agricultural Incentives. The authors are grateful for discussions with John Baffes and helpful comments from seminar participants including Larry Hinkle, Elke Kreuzwieser, Will Masters and Maurice Schiff, and for funding from the UK's Department for International Development and the Bank-Netherlands Partnership Program. 


\begin{abstract}
Four West African nations have demanded that the WTO’s Doha Development Agenda include a Cotton Initiative that involves two issues: cutting cotton subsidies and tariffs, and assisting farm productivity growth in Africa. This paper provides estimates of the potential economic impacts of (a) complete or partial removal of cotton subsidies and import tariffs globally and (b) cotton productivity growth through the adoption of genetically modified (GM) cotton varieties. Use is made of the latest version of the GTAP database and model. Our results confirm that - unlike for other agricultural subsidies and tariffs - for cotton it is subsidy reductions rather than tariff cuts that would make by far the largest impact. For Sub-Saharan Africa the potential gains are huge relative to the effects on that region of reforming other merchandise trade policies. And they could be more than doubled if that reform provided the cash for farmers to take advantage of the biotechnology revolution and adopt GM cotton varieties. But those potential gains, and the affordability of switching to costly GM seed, depend crucially on the extent to which high-income countries are willing to lower domestic support to their cotton farmers.
\end{abstract}

\title{
JEL codes: D58, F17, Q16, Q17
}

Key words: subsidy and tariff reform, computable general equilibrium modeling, economic welfare, GMOs, cotton biotechnology

\section{Contact author:}

Kym Anderson

Development Research Group

The World Bank

Mailstop MC3-303

1818 H Street NW

Washington DC 20433 USA

Phone +1 2024733387

Fax +12025221159

kanderson@worldbank.org 


\section{The World Trade Organization's Doha Cotton Initiative: A Tale of Two Issues}

\section{Introduction}

For many developing countries, especially in Africa and Central Asia, cotton is an important cash crop. It is receiving attention of late because four poor cotton-exporting West African countries (the Cotton-4: Benin, Burkina Faso, Chad and Mali) have demanded that cotton subsidy and import tariff removal be part of the World Trade Organization’s Doha Development Agenda (DDA). Cotton subsidies are mostly provided by governments in high-income countries, and part of the US cotton subsidy program has been ruled illegal following a WTO dispute settlement case brought by Brazil. Hence some reform can be expected soon, especially if the DDA is to live up to its name of being a development round (Sumner 2006).

This paper seeks to provide estimates of what is at stake in terms of cotton production, trade and economic welfare in African and other developing countries. Specifically, how much would Sub-Saharan Africa gain from removal of all cotton subsidies and tariffs relative to removal of such distortions to other merchandise trade globally? How would the welfare of cotton-importing developing countries with export interests in textiles and clothing be affected by such reform? What would be the relative contributions of different countries’ policies - and of domestic supports, export subsidies and import tariffs - to the global gains from removal of those measures? And how would 
the gains from full reform compare with the gains that could be expected if and when (a) the US complies with its WTO obligations as laid out in the WTO's dispute settlement Panel and Appellate Body reports (WTO 2004b, 2005a) and (b) the partial reforms proposed in the Hong Kong Trade Ministerial meeting in December 2005 are implemented as part of the DDA?

The Cotton Initiative under the WTO's DDA has not only the trade policy reform component but also a development component (WTO 2004a,c). The latter is aimed at boosting the international competitiveness of cotton producers in low-income (especially West African) cotton-exporting countries. One prospective way to do that is for governments of those countries to allow the adoption of new varieties of cotton emerging from the biotechnology revolution, the affordability of which will be greater in the absence of cotton market distortions. We therefore compare the estimated gains from cotton subsidy and tariff reform with the prospective gain from wider adoption by developing countries of genetically modified (GM) cotton, and also ask: how much greater would be the gains to cotton-producing developing countries from GM cotton adoption if global cotton markets were not distorted by subsidies and tariffs?

After presenting a brief background to the world's cotton market in Section 2, this paper seeks to address these questions by using a well-received model of global economy known as GTAP (developed by Purdue University's Global Trade Analysis Project) and a slight modification of the latest version of its related trade and protection database, described in Section 3. Empirical simulation results are presented in Section 4 for full trade and subsidy reform and in Section 5 for partial cotton policy reform either by the US in response to the WTO dispute settlement case brought against it by Brazil or as 
proposed at the Hong Kong Trade Ministerial of the DDA. These are then compared in Section 6 with the estimated effects of GM cotton adoption by various country groups. The paper concludes with a summary of findings and draws out implications for developing country negotiators in the WTO's Doha round.

\section{Background: the global cotton market}

Cotton production is highly concentrated in several respects. One is that most production is in a few countries: as of 2005/06, nearly half is produced by just China and the United States, and that rises to more than two-thirds when India and Pakistan are added and to more than three-quarters when Brazil and Ukbekistan are included. Also highly concentrated are exports of cotton lint, with the US, Australia, Uzbekistan and Brazil accounting for almost two-thirds of the world's exports, while the cotton-four in West Africa and the other four countries in Central Asia bring that total to almost fourfifths (Appendix Tables A1 and A2) Both production of cotton and its export patterns are distorted very considerably by subsidies to both as well as by tariffs on cotton, textiles and clothing imports (the size of which are shown in Appendix Table A3).

Cotton production is also concentrated in the sense that a number of low-income countries depend heavily on cotton for earning foreign exchange. This is especially true of several countries in Sub-Saharan Africa (Benin, Burkina Faso, Chad, and Mali) and in Uzbekistan where cotton accounts for more than one-fifth of merchandise exports and, for another six countries in those regions, cotton's share is between 5 and 12 percent. In 2002 all but three of those eleven African and Central Asian countries had average per 
capita incomes of less than 80 US cents per day (Appendix Table A2). And since much of their cotton production is exported, they compete directly in international markets with highly subsidized exports from the United States.

Cotton usage, on the other hand, is distributed across countries roughly in proportion to their volumes of textile production. ${ }^{1}$ Because of high domestic usage by exporters of textiles and clothing in developing Asian countries (and Mexico because of its preferential access to the US and Canadian markets under NAFTA), even relatively large cotton producers such as China, Pakistan and India (see column 1 of Table 1) export only a small fraction of their crop, in contrast to Sub-Saharan Africa where textile production is relatively minor. This explains the pattern of net exports of cotton and textiles across regions (columns 2 and 3 of Table 1), an understanding of which is helpful in explaining the signs of the welfare effects of the technology and policy shocks considered below.

\section{The GTAP model and database}

The standard Global Trade Analysis Project (GTAP) model of the global economy is used to provide insights into the likely effects of reforming cotton subsidy and trade policies globally and of governments allowing GM cotton technology adoption in some countries without and then with cotton trade and subsidy policy reform globally. The GTAP model (see Hertel (1997) for comprehensive documentation) is a neo-classical multi-regional, static, applied general equilibrium model that assumes perfect

1 That usage pattern has been distorted considerably by import tariffs on textiles and clothing, even after the removal by end-2004 of quotas restricting exports of those products from developing countries: compare the columns in Appendix Table A4 with and without protection as of 2005. 
competition, constant returns to scale and unchanging aggregate employment of all factors of production. We use the latest Version 6.05 of the GTAP database (see Dimaranan and McDougall, 2005), which draws on global economic structures, policies and trade flows of 2001. The GTAP model has been aggregated to depict the global economy as having 27 sectors and 38 regions (to highlight the main participants in the world's cotton markets, two of which are newly disaggregated countries: Nigeria and Pakistan). Trade is modeled using a nested Armington structure in which aggregate import demand for each sector's product is the outcome of allocating domestic absorption between domestic goods and aggregate imports, and then aggregate import demand is allocated across source countries to determine the bilateral trade flows.

Two modifications have been made to the structure of protection in Version 6.05 of the GTAP database. One relates to cotton subsidies in the United States. In Version 6.05, which reflects subsidy notifications to the WTO, the subsidies showing for the US in 2001 are much less than actually paid through its various and complex cotton programs: $\$ 1.0$ billion as production subsidies and zero as export subsidies, compared with an average annual total payment of $\$ 3.0$ billion for the 2000-2002 period according to Baffes (2005, Table 4, drawing on official data from the USDA). We therefore adjusted the subsidy rates to raise overall payments to that $\$ 3$ billion level (of which direct payments and countercyclical payments are paid per unit of land, marketing loan benefits and crop insurance subsidies are paid as input subsidies, and coupled output payments plus Step 2 payments to US cotton textile producers and to US cotton exporters, along with export credit guarantees, are paid as production subsidies). ${ }^{2}$ The

2 The latter two are export subsidies but, since an export subsidy is equivalent to a production subsidy plus a consumption tax at the same rate, and since US buyers of domestically produced cotton 
resulting subsidy rates are shown in Appendix Table A3, along with information on the (relatively small) tariffs on cotton imports. ${ }^{3}$ For the US it amounts to a production subsidy in 2001 of 40 percent. This may be conservative, as it compares with a recent projection for 2004-06 of 56 percent with the Step 2 program intact and 46 percent if it is repealed without re-instrumentation (Sumner 2005, Table 3).

The other modification to the GTAP protection database is to take account of the completion of the implementation of the Uruguay Round Agreement on Textiles and Clothing by end-2004, at which time all trade-restricting quotas were abolished and were replaced by a tariff-only regime. We then recalibrate the model's baseline by implementing that protection change, and the change in US cotton subsidy rates, before running the simulations described below. ${ }^{4}$

receive a consumption subsidy to compensate for the price-raising effect of the export subsidies on cotton, the two elements in the Step 2 program sum to the equivalent of just a cotton production subsidy. That program's payments amounted to one-seventh of total dollars of cotton supports during 2000-02 (Baffes 2005, Table 4) and, if it were not repealed, would amount to one-sixth during 2004-06 (Sumner 2005, Table 3). In any case they were found to be illegal recently by the WTO's Dispute Settlement Panel and Appellate Body (WTO 2004b, 2005a). As a result, on 1 February 2006 the US Congress agreed to reform both components of the Step 2 program by 1 August 2006. How this reform impacts the market depends on the extent of re-instrumentation of that portion of the overall support, as discussed on Section 5 below.

3 No cotton subsidies are shown for China in the GTAP protection database, even though there have been some in past years. According to Huang, Rozelle and Chang (2004), the degree of protection varied from positive to negative during 2001 and the key intervention was an export subsidy. Since then China has committed to zero export subsidies, as part of its WTO accession agreement. Those zero entries in Table A3 also are consistent with the OECD's recent Producer Support Estimates for China (OECD 2006), which for 2001 show no direct subsidy payments and a slightly negative nominal rate of protection for cotton producers. For an up-to-date assessment of China's cotton policies, see Shui (2005).

4 US and other cotton subsidy programs have been the subject of intense analysis in recent years, although mostly by partial rather than general equilibrium modelers. For reviews of that literature, see FAO (2004), Baffes (2005) and Sumner (2006). 


\section{The global cost of cotton subsidies and tariffs}

What is the cost of current distortions to cotton markets or, equivalently, what would be the effects of eliminating all cotton subsidies and import tariffs, as called for by African cotton-exporting countries as part of the WTO's Doha Development Agenda? Given the extent of subsidies to cotton production and exports, and of tariffs on cotton imports as of 2001 (modified as described in the previous section), we estimate using the GTAP model that their removal would boost global economic welfare by $\$ 283$ million per year, ${ }^{5}$ and would raise the price of cotton in international markets by an average of 12.9 percent. $^{6}$ The price rise ensures that all cotton-exporting countries would benefit, while net importers of cotton would be worse off, as shown in the right-hand columns of Table 1.

What is striking about the welfare effects is their distribution among developing countries (Table 2 and Figure 1). Especially noteworthy is the relatively large benefit bestowed on Sub-Saharan Africa, of $\$ 147$ million per year. About two-fifths of that would go to the Cotton-4 and another one-fifth to other West African countries. This is driven by an estimated increase in Sub-Saharan African cotton output and net farm income of nearly one-third, and in the real value of the region's cotton exports of more than 50 percent. By contrast, cotton output and exports would fall by one-quarter in the United States and would halve in the EU (middle columns of Table 1). That would raise

\footnotetext{
$5 \quad$ Of course if textile and clothing tariffs also were removed, global welfare would increase far more: by an extra $\$ 6.8$ billion per year, according to our GTAP model results.

$6 \quad$ This is almost identical to the 12.6 percent claimed by Brazil using a model developed by FAPRI (FAPRI 2005) and close to the 10 percent estimated by Sumner (2006, p. 282), which is also the simple average of the studies surveyed by Baffes (2005, p. 122) although the range reported by Baffes is up to 30 percent. When we alter the GTAP trade elasticities to the larger ones used in the World Bank's Linkage model (see van der Mesbrugghe 2005), our estimate of 12.9 percent falls to 11.9 percent.
} 
Sub-Saharan Africa's share of global cotton exports from 12 to 17 percent, and the share of all developing countries from 52 to 72 percent.

Also striking is a comparison of the welfare result from cotton reform with that from removing all merchandise tariffs and agricultural subsidies. While the latter gain is nearly 300 times as great as the former globally, for Sub-Saharan Africa cotton reform is crucial: its potential contribution to the region's welfare of $\$ 147$ million per year is onefifth of the estimated $\$ 733$ million gain for the region from the freeing of all goods markets globally, according to our GTAP model results. It is therefore not surprising that some African trade negotiators have threatened to walk out of the WTO's Doha round of talks if substantial reforms to cotton policies are not included in the final Doha agreement - in which case the global cost of not reforming cotton would be many times greater than implied in Table 1.

If the distortions to cotton markets were removed, the final row of Table 2 shows that the United States' policy reform would be responsible for more than half of the global gain. Perhaps more surprising is the result that the EU25 is responsible for nearly all of the rest, but that is mainly because the cost of the EU's policies to its own economy is so high. Even so, the estimated cost to Sub-Saharan Africa is only half due to US policies and only one-quarter to developing countries' policies, with most of the rest due to EU cotton policies. The reason the latter are so much more important to Sub-Saharan Africa has to do with the pattern of bilateral trade in cotton. As shown in Appendix Table A5, Sub-Saharan African cotton is sold in direct competition with EU cotton in EU and East Asian markets. 
Table 2 also shows that export subsidy removal would contribute almost none of the global benefits from reform, and cotton tariff removal would account for only oneninth of the global gain, with the other eight-ninths due to cutting domestic support programs. This latter result contrasts markedly with that for the removal of all agricultural subsidies and tariffs (to which cotton is a tiny contributor), whereby tariff removal accounts for a huge 93 percent of the global benefits and domestic support programs only 5 percent (Anderson, Martin and Valenzuela 2006).

Turning to the impacts on cotton farmers' incomes of such reform, Table 3 suggests that they would decline by one-sixth in the United States and by just over half in the EU. In virtually all other regions, however, they are estimated to rise. Crucially, they would rise by a huge 30 percent in Sub-Saharan Africa and around 40 percent in West Africa in particular - more than three-quarters of which is due to cuts to domestic support programs. The relative distribution of those gains across key developing countries is depicted in Figure 2. It is no wonder that cotton-exporting countries in Africa are calling for large cuts to those subsidies as part of the Cotton Initiative within the WTO's Doha Development Agenda (DDA), and for assistance to increase their cotton productivity and responsiveness to higher export prices.

\section{Prospective gains from partial reform of cotton subsidies and tariffs}

While the full reform results presented above are not likely to materialize in the immediate future, they provide a useful benchmark against which to compare the estimated effects of partial reforms. In this section we consider two partial reform scenarios: liberalization in the United States alone, as a possible response to the outcome 
of the WTO dispute settlement case brought against it by Brazil; and a broader liberalization consistent with what was agreed at the Hong Kong Trade Ministerial in December 2005 as part of the DDA.

\section{US-only partial reform following the WTO dispute settlement case}

How much cotton reform can be expected in the United States as a result of the US being found not in compliance with its WTO obligations, as laid out in the WTO's dispute settlement Panel and Appellate Body reports (WTO 2004b, 2005a)? The reports ruled that the Step 2 program and the export credit guarantees were prohibited export subsidies and domestic-content subsidies. They also ruled that all US cotton production subsidies are not minimally trade-distorting and so should be in the amber box rather than the green box (to use the terminology of the Uruguay Round Agreement on Agriculture). On the first, the US already has agreed to repeal the two parts of its Step 2 program (passed by the US Congress on 1 February 2006). That program provided an export subsidy to cotton producers and a consumption subsidy to US users of domestically produced cotton (the sum of which in economic terms is equivalent to a production subsidy of the same rate). At one extreme, if those dollars of support to US cotton farmers through the Step 2 program are completely re-instrumented to direct production subsidies, there would be effectively no global market impact of that repeal. At the other extreme, if there was zero re-instrumentation and the total expenditure on cotton support was reduced by the full amount of the Step 2 payments, this would be equivalent in 200002 to a one-seventh reduction in the aggregate subsidy to US cotton production. 
Turning to the second part of the WTO ruling, if US cotton producer subsidies are now to be counted as part of the country's amber box measures, they should not exceed the support provided in 1992 (the limit year under the Uruguay Round Agreement on Subsidies and Countervailing Measures), which was $\$ 2.0$ billion. In fact payments in 2000-2002 averaged \$3.0 billion, suggesting they should be cut by one-third in order to comply with the WTO ruling - or by more than twice the amount associated with repealing the Step 2 program even if there were no re-instrumentation of that program's dollars to domestic producer support programs.

To simulate a US reform that would fully comply with those WTO rulings, we ran a scenario in which not only the Step 2 program is removed but also domestic producer subsidies are cut by one-third, from $\$ 3$ billion to $\$ 2$ billion. The results are reported in the first columns of Tables 4 and 5, together with those from a more-extensive partial reform which we outline below.

\section{Partial reform that might be achieved in the WTO's Doha round}

The WTO’s Hong Kong Trade Ministerial meeting of the Doha Development Agenda (DDA) in December 2005 agreed that cotton export subsidies be eliminated during 2006, that least-developed countries get duty free access for their cotton exports to high-income countries by the time implementation of the DDA commences, and that domestic cotton subsidies be reduced faster and more ambitiously than other agricultural domestic support programs during DDA implementation (WTO 2005b). How far might that go towards yielding the potential gains to low-income countries from full reform as 
reported above? To address this question, we ran another partial liberalization scenario in which we:

- remove all cotton export subsidies globally,

- remove tariffs on imports by all high-income countries (HICs) of cotton from pertinent UN-defined least-developed countries (LDCs, comprising South Asia excluding India, Pakistan and Sri Lanka plus Sub-Saharan Africa excluding Nigeria and the Southern African Customs Union in terms of our regions), ${ }^{7}$ and

- reduce by one-third all applied cotton production subsidies in all high-income countries (not just in the US as in the previous partial reform scenario). ${ }^{8}$

\section{Comparison of the two partial-reform scenarios with the full-liberalization results}

Impacts of this Doha partial reform simulation and the US-only partial reform simulation on regional welfare and on cotton net farm income are reported in Table 4 and in Figures 1 and 2, and the effects on cotton output and exports are shown in Table 5, from which several points are worth stressing.

First, the US-only reform would provide virtually all of the net benefits to the US economy that are generated by the Doha scenario, but only around three-fifths of the estimated net welfare and net cotton income effects, and two-fifths of the export effects,

\footnotetext{
$7 \quad$ For the list of LDCs, see http://www.un.org/special-rep/ohrlls/ldc/list.htm. Due to regional aggregations in the GTAP dataset we use, our Sub-Saharan African group has some non-LDCs (including Zimbabwe, although it - like the three poorest Central Asian nations - probably now qualifies as an LDC) while LDCs in other regions are not so classified because they are too small a part of 'rest of region $\mathrm{x}$ ' categories.

$8 \quad$ There may be also some reduction in bound cotton tariffs as a result of the non-agricultural market access negotiations, but we ignore that by assuming applied tariffs are sufficiently below bound rates ('binding overhang') for the latter to remain unchanged, which is especially likely in developing countries as they are to be allowed to make lesser cuts than high-income countries (under so-called Special and Differential Treatment, SDT - see Anderson and Martin 2006). Similarly, because of binding overhang also in domestic subsidies, and SDT, we assume developing countries will not have to lower their cotton production subsidies.
} 
that Sub-Saharan Africa can expect from Doha cotton reform. Thus while the WTO dispute settlement case is potentially very helpful to non-US cotton producers, at best it is likely to generate barely half the benefits that could come from Doha cotton reform.

Second, by showing there the contributions of trade measures (export subsidy and import tariff reform) separately, it is clear that virtually all the gains from the Doha partial reform would come from reducing domestic producer support programs. This is not surprising given the earlier results in Table 2 from full reform by instrument, and the knowledge that LDCs already enjoy close to duty free access to HIC markets through various preference schemes.

Third, while the global welfare gains from the Doha partial reform are two-thirds those from full reform, much of the former would accrue to those cutting their domestic supports, most notably the United States. The overall welfare benefits from the Doha reform simulation to Sub-Saharan Africa and to Central Asia, by contrast, are only onequarter what they would be from full removal of all cotton programs. That is also true of the benefits to Sub-Saharan Africa's cotton farmers.

Fourth, Sub-Saharan Africa's cotton output and exports would rise four times as much (and Central Asia's two-and-a-half times as much) under full reform as under the Doha partial reform scenario. If the extent of reduction in applied domestic support to cotton farmers in HICs was less than the one-third assumed here, these differences would be even greater. That is, how much poor African countries and their cotton farmers gain from the DDA Cotton Initiative will hinge crucially on the extent of reform to applied (as distinct from WTO-bound) domestic subsidies. 
Finally, what difference would these scenarios make to the average price of cotton in international markets? Under full reform, that average price is estimated to rise by 12.9 percent, while in the Doha and US-only scenarios it rises by just 4.4 and 3.2 percent, respectively.

\section{What impact would GM cotton adoption have on the gains from trade reform?}

The Cotton Initiative involves two parts: in addition to trade and subsidy reform, the WTO's General Council also has attached importance to development aspects of the Cotton Initiative, stressing the complementarity between the trade and development components (WTO 2004a,c). The latter is aimed at boosting the international competitiveness of cotton production in low-income countries. One prospective way to do that is for governments of those countries to allow the adoption of new varieties of cotton emerging from the biotechnology revolution. How do the above estimated gains from cotton subsidy and tariff reform compare with the prospective gains from wider adoption by developing countries of genetically modified (GM) cotton? And how much greater would be those gains to cotton-producing developing countries from GM cotton adoption if global cotton markets were not distorted by subsidies and tariffs, and vice versa?

To simulate the economic effect of adoption of GM cotton, Anderson, Valenzuela and Jackson (2006) assume total factor productivity (TFP) in cotton production would rise by 5 percent in most adopting countries, net of any higher cost of GM seed. This output-augmenting, Hicks-neutral TFP shock is a conservative estimate of the gain to 
farmers, according to experience to date (Marra, Pardey and Alston 2002; Qaim and Zilberman 2003; Huang et al. 2004) and bearing in mind that typically, in a small number of years after GM cotton adoption is allowed, more than four-fifths of production moves to GM varieties. For India and Sub-Saharan Africa other than South Africa, however, a TFP shock of 15 percent is assumed. Even that higher value is conservative for those countries, according to Qaim and Zilberman (2003), because those countries' yields per hectare with conventional varieties are less than one-third yields in the rest of the world, and the GM field trials in India have been boosting yields by as much as 60 percent. $^{9}$

Two GM cotton adoption simulations are presented, bearing in mind that by the GTAP Model's base year of 2001 the US, Australia and South Africa had fully adopted GM cotton and China was half way through its adoption process. The first simulation has China completing its adoption process and all other countries except the rest of SubSaharan Africa adopting GM cotton, while in the second simulation Sub-Saharan Africa also adopts. ${ }^{10}$

If all other countries adopt GM cotton, cotton output in the early-adopting countries falls in response to the output expansion in newly adopting regions. If SubSaharan Africa continues to procrastinate, its cotton output, net farm income and exports would fall further. By contrast, if Sub-Saharan Africa also were to embrace this technology, its cotton industry would expand more than any other region's, and this

\footnotetext{
$9 \quad$ There are also benefits from insect-resistant Bt cotton in terms of improved health for farmers (see Hossain et al. 2004), and also less pesticide damage to soil and water, but these benefits are ignored in what follows.

10 The reason it is worth examining separately the impact of adoption by the rest of Sub-Saharan Africa is that the region has a history of very slow adoption of new agricultural technologies in the 1970s and 1980s, and during the 1990s its investments in agricultural R\&D grew only 1 percent per year and spending actually fell in about half the countries for which data exist (Science Council 2005).
} 
would more than make up its losses to 2001 from adoption by the first four adopters (Anderson, Valenzuela and Jackson 2006, Table 5).

Even without Sub-Saharan Africa embracing this new biotechnology, global welfare would jump \$2.0 billion per year if other countries adopt GM cotton; but adoption by the rest of Africa would raise that global benefit to $\$ 2.3$ billion, with twothirds of that extra $\$ 0.3$ billion being enjoyed by Africa. Asia’s developing countries that are net importers of cotton gain even if they grow little or no cotton (see columns 1 and 2 of Table 6), because the international price of that crucial input into their textile industry would be lower in these scenarios. With complete catch-up as in the second of these scenarios, the gains to Central Asia, Sub-Saharan Africa and South Asia are 10, 13 and 23 times greater than the global gains when expressed as a percentage of regional GDP (Anderson, Valenzuela and Jackson 2006, Table 6). South Asia’s are especially large because it is a large producer and user of cotton.

The estimate of the global benefits from full GM cotton adoption by developing countries is eight times larger than the above estimate of the global gain from complete removal of all cotton subsidies and tariffs, and twelve times larger than the global gain from the Doha partial cotton reform simulation. The differences are less marked for SubSaharan Africa, but even so its estimated gain from adopting GM cotton varieties is well above that from full removal of all trade-distorting cotton policies and around six times that from the Doha partial reform simulation considered above.

If all distortions to cotton markets were removed, that global estimate would be virtually no different, for reasons explained in Alston, Edwards and Freebairn (1988) and Anderson and Nielsen (2004). But the gains to developing countries in the absence of 
distortionary cotton policies would be slightly greater (12 percent so in the case of SubSaharan Africa), while those to high-income countries would be less (middle columns of Table 6).

Were these two reforms (GM catch-up and subsidy removal) to occur simultaneously, they would reinforce each other in Sub-Saharan Africa as each expands the region's cotton production and exports and so makes the gain from the other change larger. This is evident in the final column of Table 6, which shows that the gain to SubSaharan Africa would then be $(\$ 223 m+\$ 147 m=) \$ 370 m$. This is equivalent to $\$ 199 m+$ $\$ 172 \mathrm{~m}$, the former appearing in column 2 of Table 6 and the latter being the gain to SubSaharan Africa from global removal of cotton subsidies and tariffs had GM catch-up occurred before that reform. Also, by comparing the final columns of Tables 4 and 6, and Figures 1 and 3, it is evident that while numerous cotton-importing developing countries lose from subsidy reform on its own, they gain when it is combined with the spread of the productivity enhancing GM cotton varieties. Clearly this is an example of complementarity between the trade and development components of the Doha Cotton Initiative. In terms of sequencing, subsidy cuts first would expand the capacity of poor farmers in low-income countries to purchase the more-expensive GM cotton seeds and make the necessary adjustments to their farming practices, and thereby increase the prospects of realizing the potential gains from GM adoption.

Finally, note that if Sub-Saharan Africa procrastinates on GM adoption while other developing countries embrace the new technology, net incomes of cotton farmers in the region are estimated to fall by 7 percent, whereas they rise by 10 percent if Sub- 
Saharan Africa also adopts. ${ }^{11}$ That difference of 17 percentage points is large even compared with the 31 percent gain for the region's cotton farmers from full removal of all cotton subsidies and tariffs globally, but it is even larger when compared with the more likely gain of just 8 percent from the Doha partial reform simulation considered above.

\section{Conclusions}

The WTO’s Hong Kong Trade Ministerial meeting of the Doha Development Agenda (DDA) in December 2005 agreed that cotton export subsidies be eliminated during 2006, that least-developed countries get duty free access for their cotton exports by the time implementation of the DDA commences, and that domestic cotton subsidies be reduced faster and more ambitiously than other agricultural domestic support programs during DDA implementation. How far that will go towards full liberalization as examined above depends on the relative strengths of the pertinent negotiators in the DDA, but the above results make clear that it will hinge very heavily on the extent to which the US and to a lesser extent EU governments are willing to cut their applied domestic subsidies to cotton production. Potentially that Doha partial reform could deliver roughly twice the gains to cotton-exporting developing countries as the reform that - in the absence of the DDA - the US might be expected to do anyway to bring its cotton support programs into conformity with its WTO obligations.

11 As well, the health of GM cotton farmers improves, and there is less contamination of water and soil, following the switch to the less chemically-intensive Bt varieties of GM cotton. These extra benefits are not included in the above welfare calculus. 
Meanwhile, there are other ways in which incomes of cotton farmers in developing countries can be enhanced. Adaptation and adoption of new genetically modified (GM) cotton varieties are one obvious way of contributing - and that is within the powers of developing countries themselves and so does not need to wait until that Doha round concludes. Indeed the above results suggest that developing country welfare would be enhanced by far more from allowing GM cotton adoption than by the removal of all cotton subsidies and tariffs. ${ }^{12}$ Furthermore, our results support the notion that the gains to developing countries from reductions in trade-distorting cotton subsidies will be even greater if GM cotton is adopted first, providing yet another reason not to delay approval of this new biotechnology, especially since genetic modification of local cotton varieties and dissemination of the new technology to many small farmers will take some years. Perhaps some of the aid-for-trade funding that is being promised as a complement to the DDA could facilitate that process.

\section{References}

Alston, J.M., G.W. Edwards and J.W. Freebairn (1988), 'Market Distortions and Benefits from Research', American Journal of Agricultural Economics 70(2): 281-88, May.

12 If embracing GM cotton helped developing country governments to streamline also the process of approving the release of GM varieties of food crops, these economies would be able to multiply their estimated $\$ 2.3$ billion gain from GM cotton adoption by at least two, according to the numbers presented in Anderson and Jackson (2005) and Anderson, Jackson and Nielsen (2005). 
Anderson, K. and L.A. Jackson (2005), 'Some Implications of GM Food Technology Policies for Sub-Saharan Africa’, Journal of African Economies 14(3): 385-410, September.

Anderson, K., L.A. Jackson and C.P. Nielsen (2005), ‘GM Rice Adoption: Implications for Welfare and Poverty Alleviation', Journal of Economic Integration 20(4): 771-88, December.

Anderson, K. and W. Martin (eds.) (2006), Agricultural Trade Reform and the Doha Development Agenda, London: Palgrave Macmillan and Washington DC: World Bank.

Anderson, K., W. Martin and D. van der Mensbrugghe (2006), 'Would Multilateral Trade Reform Benefit Sub-Saharan Africa?’ Journal of African Economies 15 (forthcoming).

Anderson, K., W. Martin and E. Valenzuela (2006), 'The Relative Importance of Global Agricultural Subsidies and Market Access', World Trade Review 5(3), November (forthcoming).

Anderson, K., E. Valenzuela and L.A. Jackson (2006), 'Recent and Prospective Adoption of Genetically Modified Cotton: A Global CGE of Economic Impacts', CEPR Discussion Paper 5568, London, March and World Bank Policy Research Working Paper, May 2006, Washington DC.

Baffes, J. (2005), “The ‘Cotton Problem””, World Bank Research Observer 20(1): 10943, Spring. 
Dimaranan, B.V. and McDougall, R.A. (eds.) (2005), Global Trade, Assistance, and Protection: The GTAP 6 Data Base, Center for Global Trade Analysis, Purdue University, West Lafayette.

FAO (2004), 'The Impact of Cotton Sector Support on developing Countries: A Guide to Contemporary Analysis', mimeo, Food and Agriculture Organization, Rome, September.

FAPRI (2005), U.S. and World Agricultural Outlook 2005, Ames IA: Food and Agricultural Policy Institute, January (see www.fapri.org).

Hertel, T.W. (ed.) (1997), Global Trade Analysis: Modeling and Applications, New York: Cambridge University Press.

Hossain, F., C.E. Pray, Y. Lu, J. Huang, C. Fan and R. Hu (2004), ‘Genetically Modified Cotton and Farmers' Health in China', International Journal of Occupational and Environmental Health 10: 307-14.

Huang, J., S. Rozelle and M. Chang (2004), 'The Nature of Distortions to Agricultural Incentives in China and Implications of WTO Accession', Ch. 6 in China and the WTO, edited by D. Bhattasali, S. Li and W. Martin, London: Oxford University Press.

ICAC (2005), TheOutlook for Cotton Supply in 2005/06, Secretariat of the International Cotton Advisory Committee (ICAC), Washington DC, September.

James, C. (2005), Global Review of Commercialized Biotech/GM Crops: 2005, Brief No. 34, International Service for the Acquisition of Agri-biotech Applications, Ithaca NY. 
Marra, M., P. Pardey and J. Alston (2002), 'The Payoffs to Agricultural Biotechnology: An Assessment of the Evidence', AgBioForum 5(2): 43-50. Downloadable at http://www.agbioforum.org/v5n2/v5n2a02-marra.pdf

OECD (2006), Producer and Consumer Support Estimates, OECD Database 1986-2004.

At www.oecd.org/document/54/0,2340,en_2649_33727_35009718_1_1_1_1,00.html

Qaim, M. and D. Zilberman (2003), 'Yield Effects of Genetically Modified Crops in Developing Countries’, Science 299: 900-02.

Science Council (2005), Science for Agricultural Development: Changing Concerns, New Opportunities, Rome: Science Council of the CGIAR, December.

Shui, S. (2005), 'Policies Toward the Chinese Cotton Industry: the Commodity Chain Analysis Approach', mimeo, Commodities and Trade Division, FAO, Rome, February.

Sumner, D.A. (2005), "Boxed in: Conflicts between U.S. Farm Policies and WTO Obligations”, Trade Policy Analysis No. 32, Cato Institute, Washington DC, 5 December.

Sumner, D.A. (2006), “Reducing Cotton Subsidies: The DDA Cotton Initiative”, in Agricultural Trade Reform and the Doha Development Agenda. K. Anderson and W. Martin eds., Ch. 10, New York: Palgrave Macmillan.

van der Mensbrugghe, D. (2005), 'LinkAGE Technical Reference Document: Version 6.0', The World Bank, Washington, DC, mimeo, and at www.worldbank.org/prospects/linkagemodel

WTO (2004a), Decision Adopted by the General Council on 1 August 2004, WT/L/579 (July Framework Agreement), Geneva: World Trade Organization, August 2. 
WTO (2004b), United States - Subsidies on Upland Cotton: Report of the Panel, WT/DS267/R, Geneva: World Trade Organization, September 8.

WTO (2004c), “Agriculture: The Cotton Sub-Committee”, Geneva: World Trade Organization, November 19. See www.wto.org/english/tratop_e/agric_e/cotton_subcommittee_e.htm WTO (2005a), United States - Subsidies on Upland Cotton: Report of the Appellate Body, WT/DS267/AB/R, Geneva: World Trade Organization, March 3.

WTO (2005b), “Ministerial Declaration: Doha Work Programme”, WT/MIN(05)/DEC, Geneva: World Trade Organization, December 22. See www.wto.org/english/thewto_e/minist_e/min05_e/final_text_e.htm 
Table 1: Cotton net farm income and net export positions in 2001, and impact of removing cotton subsidies and tariffs ${ }^{\mathrm{a}}$ on cotton output, exports, net farm income and economic welfare

(percent and 2001 US\$m)

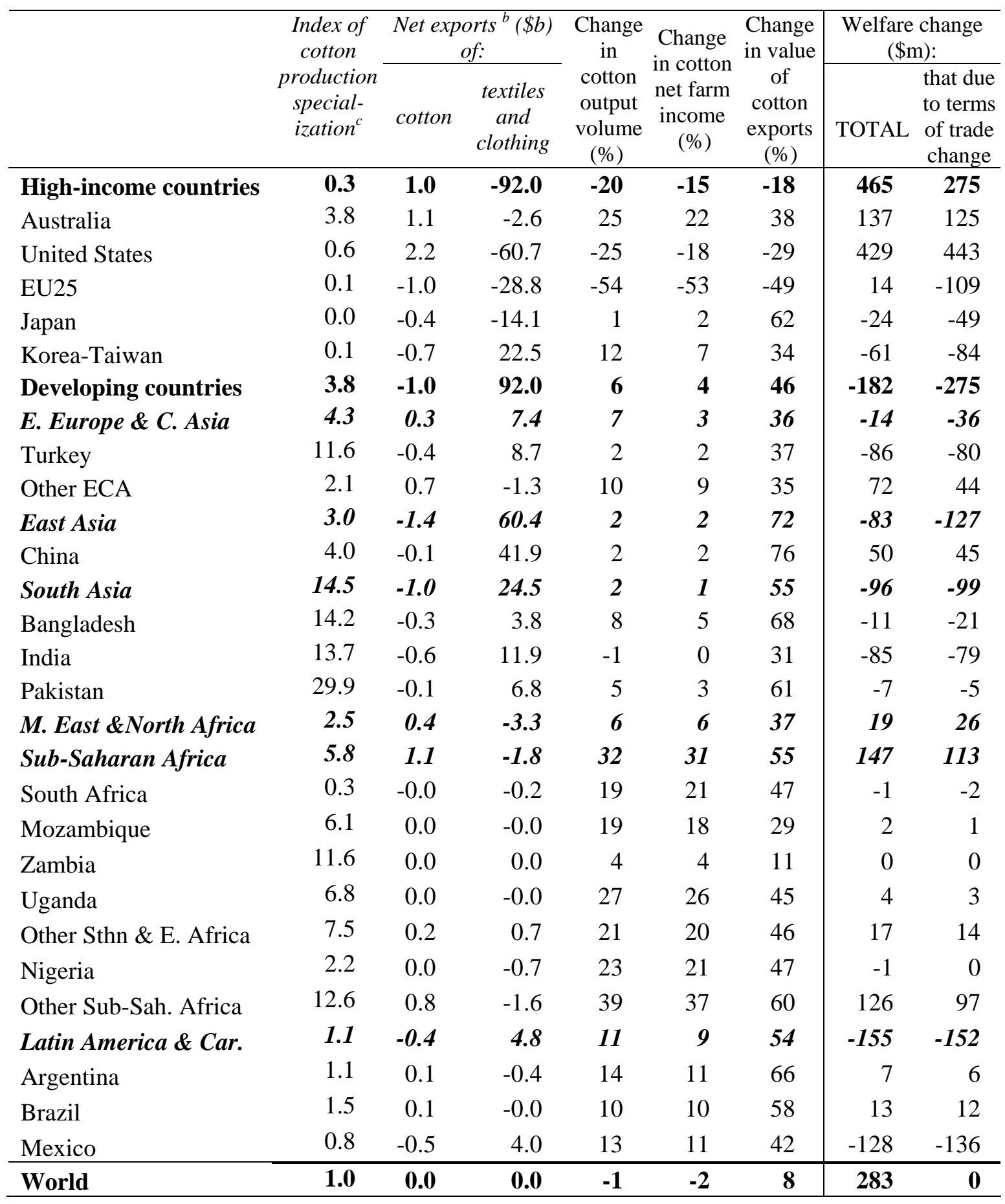

${ }^{a}$ Removal of those distortions left after the phase-out of the quotas at the end of 2004

${ }^{\mathrm{b}}$ Exports minus imports, both valued at f.o.b. prices as in the GTAP database 6.05 
' Cotton's national share in GDP relative to the global share. In the GTAP database the sector is 'plant-based fibres' and so includes such products as flax (important only for Bangladesh in the above countries)

Source: Authors’ GTAP model simulation results 
Table 2: Contribution to national economic welfare that would result from removing cotton subsidies and tariffs, ${ }^{\mathrm{a}}$ by region and by policy instrument

(equivalent variation in income in 2001 US\$ million)

\begin{tabular}{|c|c|c|c|c|c|c|c|c|}
\hline \multirow[b]{2}{*}{ Benefiting region: } & \multicolumn{5}{|c|}{ By reforming region: } & \multicolumn{3}{|c|}{ By policy instrument: } \\
\hline & US & EU25 & $\begin{array}{l}\text { All other } \\
\text { high- } \\
\text { income } \\
\text { countries }\end{array}$ & $\begin{array}{l}\text { Develop- } \\
\text { ing } \\
\text { countries }\end{array}$ & $\begin{array}{l}\text { TOTAL, } \\
\text { WORLD }\end{array}$ & Tariff & $\begin{array}{l}\text { Export } \\
\text { subsidy }\end{array}$ & $\begin{array}{c}\text { Domestic } \\
\text { support }\end{array}$ \\
\hline High-income countries & 374 & 109 & $\mathbf{0}$ & -17 & 465 & 15 & -7 & 457 \\
\hline Australia & 109 & 14 & 8 & 6 & 137 & 2 & 2 & 134 \\
\hline United States & 401 & 8 & 1 & 19 & 429 & 18 & 1 & 411 \\
\hline EU25 & -64 & 110 & -5 & -28 & 14 & 6 & -9 & 18 \\
\hline Japan & 0 & -15 & -2 & -7 & -24 & -4 & -1 & -19 \\
\hline Korea-Taiwan & -52 & -3 & -2 & -5 & -61 & -8 & 0 & -54 \\
\hline Developing countries & -224 & 22 & -3 & 24 & -182 & 13 & 7 & -204 \\
\hline E. Europe \& C. Asia & -25 & 2 & 1 & 7 & -14 & 1 & 0 & -14 \\
\hline Turkey & -61 & -17 & 0 & -9 & -86 & -1 & -2 & -83 \\
\hline Other ECA & 38 & 24 & 1 & 7 & 72 & 2 & 2 & 69 \\
\hline East Asia & -54 & -15 & -6 & -9 & -83 & -20 & -2 & -63 \\
\hline China & 60 & -12 & 2 & -1 & 50 & -13 & 0 & 62 \\
\hline South Asia & -71 & -5 & -3 & -17 & -96 & 5 & -1 & -99 \\
\hline Bangladesh & -11 & -2 & -1 & 2 & -11 & 6 & 0 & -16 \\
\hline India & -57 & -6 & -1 & -20 & -85 & 0 & 0 & -84 \\
\hline Pakistan & -7 & 2 & -2 & 0 & -7 & -1 & -1 & -5 \\
\hline M. East \& North Africa & 8 & -4 & 1 & 14 & 19 & 1 & 8 & 10 \\
\hline Sub-Saharan Africa & 72 & 33 & 4 & 39 & 147 & 32 & 2 & 112 \\
\hline South Africa & 0 & 0 & 0 & -1 & -1 & 0 & 0 & -1 \\
\hline Mozambique & 1 & 1 & 0 & 0 & 2 & 0 & 0 & 1 \\
\hline Zambia & 0 & 0 & 0 & 0 & 0 & 0 & 0 & 0 \\
\hline Uganda & 2 & 1 & 0 & 0 & 4 & 0 & 0 & 4 \\
\hline Other Sthn \& E. Africa & 10 & 5 & 1 & 2 & 17 & 2 & 0 & 16 \\
\hline Nigeria & 0 & -1 & 0 & 0 & -1 & 0 & 0 & -1 \\
\hline Other Sub-Sah. Africa & 59 & 27 & 3 & 36 & 126 & 30 & 2 & 93 \\
\hline Latin America \& Car. & -154 & 9 & 0 & -10 & -155 & -6 & 0 & -150 \\
\hline Argentina & 2 & 3 & 0 & 2 & 7 & 2 & 0 & 4 \\
\hline Brazil & 6 & 6 & 0 & 1 & 13 & 0 & 0 & 12 \\
\hline Mexico & -120 & -2 & 0 & -6 & -128 & -2 & 0 & -125 \\
\hline World & 149 & 130 & -4 & 7 & 283 & 28 & 0 & 253 \\
\hline
\end{tabular}

${ }^{a}$ Removal of those distortions left after the eventual phase-out of the quotas under the Multifibre Agreement at the end of 2004

Source: Authors’ GTAP model simulation results 
Table 3: Contribution to net incomes of cotton farmers that would result from removing cotton subsidies and tariffs, ${ }^{\text {a }}$ by region and by policy instrument

(percent change in value added)

\begin{tabular}{|c|c|c|c|c|c|c|c|c|}
\hline \multirow[b]{2}{*}{ Benefiting region: } & \multicolumn{5}{|c|}{ By reforming region: } & \multicolumn{3}{|c|}{ By policy instrument: } \\
\hline & US & EU25 & $\begin{array}{l}\text { All other } \\
\text { high- } \\
\text { income } \\
\text { countries }\end{array}$ & $\begin{array}{l}\text { Develop- } \\
\text { ing } \\
\text { countries }\end{array}$ & $\begin{array}{l}\text { TOTAL, } \\
\text { WORLD }\end{array}$ & Tariff & $\begin{array}{l}\text { Export } \\
\text { subsidy }\end{array}$ & $\begin{array}{c}\text { Domestic } \\
\text { support }\end{array}$ \\
\hline High-income countries & -12.9 & -3.2 & -0.4 & 1.2 & -15.4 & 0.4 & 0.1 & -15.9 \\
\hline Australia & 22.4 & 2.5 & -4.2 & 1.5 & 22.2 & 0.2 & 0.3 & 21.6 \\
\hline United States & -20.1 & 1.0 & 0.3 & 0.9 & -17.9 & 0.3 & 0.1 & -18.3 \\
\hline EU25 & 8.6 & -66.2 & 0.4 & 3.9 & -53.3 & 2.3 & 0.5 & -56.1 \\
\hline Japan & 2.9 & 0.2 & -1.9 & 0.3 & 1.5 & 0.1 & 0.0 & 1.4 \\
\hline Korea-Taiwan & 7.2 & 0.6 & -1.1 & 0.2 & 6.9 & -0.3 & 0.0 & 7.2 \\
\hline Developing countries & 3.8 & 1.3 & 0.1 & -0.9 & 4.3 & -0.2 & -0.1 & 4.6 \\
\hline E. Europe \& C. Asia & 3.3 & 2.3 & 0.1 & -2.4 & 3.3 & 0.0 & 0.1 & 3.1 \\
\hline Turkey & 2.8 & 1.3 & 0.1 & -2.0 & 2.1 & 0.0 & 0.1 & 2.0 \\
\hline Other ECA & 4.3 & 4.0 & 0.2 & -3.3 & 5.2 & 0.0 & 0.2 & 5.1 \\
\hline East Asia & 1.4 & 0.5 & 0.1 & -0.1 & 1.9 & -0.2 & 0.0 & 2.0 \\
\hline China & 1.1 & 0.5 & 0.0 & -0.1 & 1.5 & -0.2 & 0.0 & 1.7 \\
\hline South Asia & 1.9 & 0.3 & 0.1 & -1.6 & 0.7 & -0.7 & 0.0 & 1.4 \\
\hline Bangladesh & 2.9 & 0.5 & 0.2 & 1.4 & 5.0 & 0.7 & 0.1 & 4.2 \\
\hline India & 1.7 & 0.2 & 0.0 & -2.4 & -0.4 & -1.1 & 0.0 & 0.7 \\
\hline Pakistan & 2.2 & 0.3 & 0.2 & 0.2 & 3.0 & 0.0 & 0.1 & 2.8 \\
\hline M. East \&North Africa & 5.7 & 3.4 & 0.3 & -3.2 & 6.1 & -0.8 & -1.9 & 8.8 \\
\hline Sub-Saharan Africa & 16.0 & 6.6 & 0.8 & 7.1 & 30.6 & 5.1 & 0.5 & 24.8 \\
\hline South Africa & 21.2 & 3.4 & 1.2 & -5.1 & 20.6 & -6.4 & 0.4 & 26.6 \\
\hline Mozambique & 10.2 & 12.7 & 0.4 & -5.8 & 17.5 & 0.3 & 0.7 & 16.4 \\
\hline Zambia & 3.1 & 2.2 & 0.4 & -2.0 & 3.6 & -2.7 & 0.2 & 6.1 \\
\hline Uganda & 14.8 & 8.5 & 0.5 & 1.7 & 25.6 & -0.3 & 0.5 & 25.4 \\
\hline Other Sthn \& E. Africa & 11.6 & 5.0 & 0.6 & 2.5 & 19.7 & 1.0 & 0.4 & 18.3 \\
\hline Nigeria & 15.7 & 2.7 & 0.5 & 2.3 & 21.3 & -0.2 & 0.3 & 21.2 \\
\hline Other Sub-Sah. Africa & 18.3 & 7.6 & 1.0 & 9.9 & 36.8 & 7.9 & 0.5 & 28.4 \\
\hline Latin America \& Car. & 9.6 & 1.3 & 0.2 & -1.8 & 9.4 & -1.1 & 0.1 & 10.4 \\
\hline Argentina & 7.6 & 1.2 & 0.2 & 1.7 & 10.7 & 1.7 & 0.1 & 9.0 \\
\hline Brazil & 8.0 & 2.5 & 0.3 & -0.5 & 10.3 & 0.3 & 0.2 & 9.9 \\
\hline Mexico & 12.8 & 0.4 & 0.1 & -2.8 & 10.5 & -0.3 & 0.0 & 10.9 \\
\hline World & -1.4 & -0.1 & 0.0 & -0.2 & -1.8 & 0.0 & 0.0 & -1.8 \\
\hline
\end{tabular}

${ }^{a}$ Removal of those distortions left after the eventual phase-out of the quotas under the Multifibre Agreement at the end of 2004

Source: Authors’ GTAP model simulation results 
Table 4: Impact of US and Doha partial reform of cotton subsidies and tariffs on economic welfare and net incomes of cotton farmers, by region

(equivalent variation in income in $2001 \mathrm{US} \$ \mathrm{~m}$, and percent change in value added)

\begin{tabular}{|c|c|c|c|c|c|c|c|c|}
\hline & \multicolumn{4}{|c|}{ Change in economic welfare (\$m) } & \multicolumn{4}{|c|}{ Change in net incomes of farmers (\%) } \\
\hline & \multirow{2}{*}{$\begin{array}{l}\text { Compl- } \\
\text { iance by } \\
\text { US to } \\
\text { WTO DS } \\
\text { panel }^{\text {b }}\end{array}$} & \multicolumn{2}{|c|}{$\begin{array}{l}\text { Doha partial } \\
\text { reform }^{\mathrm{a}}\end{array}$} & \multirow[t]{2}{*}{$\begin{array}{l}\text { Full } \\
\text { reform }\end{array}$} & \multirow{2}{*}{$\begin{array}{c}\text { Compliance } \\
\text { by US to } \\
\text { WTO DS } \\
\text { panel }^{\text {b }}\end{array}$} & \multicolumn{2}{|c|}{$\begin{array}{l}\text { Doha partial } \\
\text { reform }^{\mathrm{a}}\end{array}$} & \multirow[t]{2}{*}{$\begin{array}{l}\text { Full } \\
\text { reform }\end{array}$} \\
\hline & & $\begin{array}{l}\text { Due to } \\
\text { trade } \\
\text { measures }\end{array}$ & Total & & & $\begin{array}{c}\text { Due to } \\
\text { trade } \\
\text { measures }\end{array}$ & Total & \\
\hline High-income countries & 210 & -9 & 280 & 465 & -4.1 & 0.1 & -5.4 & -15.4 \\
\hline Australia & 33 & 1 & 41 & 137 & 7.7 & 0.3 & 7.5 & 22.2 \\
\hline United States & 229 & 0 & 231 & 429 & -6.6 & 0.1 & -6.0 & -17.9 \\
\hline EU25 & -29 & -9 & 42 & 14 & 4.2 & 0.6 & -20.9 & -53.3 \\
\hline Japan & 3 & -1 & -4 & -24 & 1.1 & 0 & 0.5 & 1.5 \\
\hline Korea-Taiwan & -18 & 0 & -20 & -61 & 2.5 & 0 & 2.5 & 6.9 \\
\hline Developing countries & -94 & 7 & -88 & -182 & 1.2 & -0.1 & 1.7 & 4.3 \\
\hline E. Europe \& C. Asia & -10 & 0 & -12 & -14 & 1.1 & 0.1 & 2.1 & 3.3 \\
\hline Turkey & -20 & -1 & -29 & -86 & 0.9 & 0.1 & 1.5 & 2.1 \\
\hline Other ECA & 10 & 1 & 17 & 72 & 1.4 & 0.2 & 3.1 & 5.3 \\
\hline East Asia & -23 & -2 & -33 & -83 & 0.5 & 0 & 0.7 & 1.9 \\
\hline China & 19 & 0 & 15 & 50 & 0.4 & 0 & 0.6 & 1.5 \\
\hline South Asia & -31 & -1 & -36 & -96 & 0.7 & 0 & 0.9 & 0.7 \\
\hline Bangladesh & -5 & 0 & -6 & -11 & 1.1 & 0.1 & 1.3 & 5 \\
\hline India & -23 & 0 & -27 & -85 & 0.6 & 0 & 0.7 & -0.4 \\
\hline Pakistan & -4 & -1 & -5 & -7 & 0.8 & 0.1 & 1.0 & 3.0 \\
\hline M. East \&North Africa & 2 & 7 & 8 & 19 & 1.8 & -1.7 & 1.3 & 6.1 \\
\hline Sub-Saharan Africa & 20 & 3 & 35 & 147 & 5.0 & 0.6 & 8.2 & 30.6 \\
\hline South Africa & 0 & 0 & 0 & -1 & 6.5 & 0.3 & 8.5 & 20.6 \\
\hline Mozambique & 0 & 0 & 0 & 2 & 3.6 & 0.6 & 9.2 & 17.5 \\
\hline Zambia & 0 & 0 & 0 & 0 & 1.0 & 0.2 & 2.1 & 3.6 \\
\hline Uganda & 1 & 0 & 1 & 4 & 4.8 & 0.4 & 8.6 & 25.6 \\
\hline Other Sthn \& E. Africa & 3 & 0 & 5 & 17 & 3.7 & 0.3 & 6.1 & 19.7 \\
\hline Nigeria & 0 & 0 & 0 & -1 & 5.0 & 0.2 & 6.3 & 21.3 \\
\hline Other Sub-Sah. Africa & 16 & 3 & 29 & 126 & 5.6 & 0.7 & 9.4 & 36.8 \\
\hline Latin America \& Car. & -52 & 0 & -50 & -155 & 3.0 & 0.1 & 3.6 & 9.4 \\
\hline Argentina & -1 & 0 & 0 & 7 & 2.2 & 0.1 & 2.8 & 10.7 \\
\hline Brazil & 0 & 0 & 2 & 13 & 2.3 & 0.2 & 3.4 & 10.3 \\
\hline Mexico & -35 & 0 & -36 & -128 & 4.1 & 0 & 4.4 & 10.5 \\
\hline World & 116 & -2 & 192 & 283 & -0.4 & $\mathbf{0}$ & -0.5 & -1.8 \\
\hline
\end{tabular}

a 'Trade measures' consist of removal of all export subsidies and removal of tariffs on highincome countries' imports of cotton from LDCs; 'Total' adds a one-third cut in domestic support in high-income countries.

${ }^{\mathrm{b}}$ Reduction by one-third in cotton production subsidies (average 2000-2002) in U.S. alone.

Source: Authors' GTAP model simulation results 
Table 5: Impact of US and Doha partial reform of cotton subsidies and tariffs on cotton production volume and real value of exports, by region

(percent)

\begin{tabular}{|c|c|c|c|c|c|c|}
\hline & \multicolumn{3}{|c|}{ Change in output volume (\%) } & \multicolumn{3}{|c|}{ Change in value of exports (\%) } \\
\hline & $\begin{array}{c}\text { Compliance } \\
\text { by US to } \\
\text { WTO DS } \\
\text { panel }^{\text {a }}\end{array}$ & $\begin{array}{l}\text { Doha } \\
\text { partial } \\
\text { reform }\end{array}$ & $\begin{array}{l}\text { Full } \\
\text { reform }\end{array}$ & $\begin{array}{c}\text { Compliance } \\
\text { by US to } \\
\text { WTO DS } \\
\text { panel }^{\text {a }}\end{array}$ & $\begin{array}{c}\text { Doha } \\
\text { partial } \\
\text { reform }\end{array}$ & $\begin{array}{l}\text { Full } \\
\text { reform }\end{array}$ \\
\hline High-income countries & -5.3 & -7.7 & -20.4 & -3.9 & -6.6 & -18.2 \\
\hline Australia & 8.6 & 8.3 & 25.0 & 11.8 & 12.3 & 38.1 \\
\hline United States & -9.7 & -8.9 & -24.6 & -11.8 & -9.7 & -29.0 \\
\hline EU25 & 4.4 & -21.7 & -54.0 & 6.1 & -18.5 & -48.8 \\
\hline Japan & 1.1 & 0.3 & 0.7 & 13.5 & 11.8 & 61.9 \\
\hline Korea-Taiwan & 4.3 & 4.2 & 11.9 & 8.6 & 11.3 & 33.6 \\
\hline Developing countries & 1.5 & 2.1 & 5.7 & 8.5 & 12.8 & 46.3 \\
\hline E. Europe \& C. Asia & 1.3 & 2.9 & 7.0 & 5.5 & 12.5 & 35.9 \\
\hline Turkey & 0.9 & 1.5 & 1.9 & 7.1 & 16.4 & 36.6 \\
\hline Other ECA & 1.6 & 4.1 & 10.0 & 5.3 & 12.2 & 35.0 \\
\hline East Asia & 0.6 & 0.8 & 2.4 & 14.1 & 18.8 & 71.9 \\
\hline China & 0.5 & 0.7 & 2.0 & 17.4 & 21.6 & 75.7 \\
\hline South Asia & 1.1 & 1.4 & 1.7 & 9.5 & 13.7 & 54.7 \\
\hline Bangladesh & 1.7 & 2.1 & 8.1 & 8.0 & 11.2 & 67.5 \\
\hline India & 1.0 & 1.2 & -0.6 & 9.0 & 13.2 & 31.1 \\
\hline Pakistan & 1.2 & 1.6 & 4.7 & 11.7 & 16.5 & 60.6 \\
\hline M. East \&North Africa & 1.8 & 1.3 & 6.2 & 9.1 & 7.1 & 37.4 \\
\hline Sub-Saharan Africa & 5.2 & 8.6 & 32.0 & 8.6 & 14.2 & 55.0 \\
\hline South Africa & 6.1 & 7.9 & 19.4 & 11.3 & 14.5 & 46.5 \\
\hline Mozambique & 3.8 & 9.9 & 19.0 & 4.9 & 12.9 & 29.2 \\
\hline Zambia & 1.0 & 2.2 & 3.8 & 2.8 & 6.1 & 10.8 \\
\hline Uganda & 5.1 & 9.1 & 27.3 & 8.2 & 14.6 & 44.5 \\
\hline Other Sthn \& E. Africa & 3.9 & 6.5 & 21.1 & 8.2 & 13.4 & 45.6 \\
\hline Nigeria & 5.2 & 6.7 & 22.7 & 10.8 & 13.7 & 47.4 \\
\hline Other Sub-Sah. Africa & 5.8 & 9.8 & 38.8 & 8.7 & 14.7 & 59.6 \\
\hline Latin America \& Car. & 3.5 & 4.3 & 11.0 & 15.3 & 15.7 & 54.0 \\
\hline Argentina & 2.7 & 3.5 & 13.6 & 12.7 & 16.3 & 66.1 \\
\hline Brazil & 2.2 & 3.3 & 9.8 & 11.0 & 16.7 & 57.6 \\
\hline Mexico & 5.3 & 5.1 & 13.0 & 13.4 & 14.4 & 42.3 \\
\hline World & -0.2 & -0.3 & -0.8 & 1.1 & 1.3 & 7.9 \\
\hline
\end{tabular}

${ }^{\text {a }}$ Reduction of one-third in production subsidies (average 2000-2002) in U.S. alone Source: Authors' GTAP model simulation results 
Table 6: Prospective effects of completing GM cotton adoption globally post-2001 on national economic welfare and net cotton farm incomes, without and with cotton subsidies and tariffs removed

\begin{tabular}{|c|c|c|c|c|}
\hline \multirow[b]{2}{*}{$\begin{array}{l}\text { (a) Effects on welfare } \\
\text { (US\$m) of: }\end{array}$} & \multicolumn{2}{|c|}{$\begin{array}{c}\text { Without cotton subsidy and } \\
\text { tariff reform }\end{array}$} & \multirow{2}{*}{$\begin{array}{l}\text { With cotton } \\
\text { subsidies and } \\
\text { tariffs first } \\
\text { removed, and } \\
\text { then GM } \\
\text { catch-up }\end{array}$} & \multirow{2}{*}{$\begin{array}{c}\text { With } \\
\text { simultaneous } \\
\text { cotton } \\
\text { subsidy/tariff } \\
\text { removal and } \\
\text { GM catch-up }\end{array}$} \\
\hline & $\begin{array}{c}\text { without } \\
\text { SSAfrican } \\
\text { GM adoption }\end{array}$ & $\begin{array}{c}\text { with } \\
\text { SSAfrican } \\
\text { GM adoption }\end{array}$ & & \\
\hline All high-income countries & 318 & 366 & 279 & 744 \\
\hline Australia & -14 & -28 & -58 & 80 \\
\hline United States & 61 & 57 & -25 & 404 \\
\hline All developing countries & 1701 & 1957 & 2043 & 1866 \\
\hline E. Europe and Central Asia & 325 & 317 & 317 & 303 \\
\hline China & 113 & 100 & 94 & 144 \\
\hline Other Southeast Asia & 31 & 63 & 83 & -48 \\
\hline India & 817 & 822 & 855 & 771 \\
\hline Other South Asia & 147 & 148 & 151 & 140 \\
\hline Middle East \& Nth Africa & 157 & 175 & 211 & 194 \\
\hline Sub-Saharan Africa & -13 & 199 & 223 & 370 \\
\hline Latin American \& Carib. & 124 & 135 & 146 & -8 \\
\hline World & 2018 & 2323 & 2322 & 2610 \\
\hline \multicolumn{5}{|c|}{$\begin{array}{l}\text { (b) Effects on net cotton farm } \\
\text { incomes (\% change) in: }\end{array}$} \\
\hline All high-income countries & -2.7 & -4.5 & -5.0 & -19.3 \\
\hline Australia & -5.6 & -9.3 & -10.3 & 9.6 \\
\hline United States & -2.7 & -3.9 & -3.7 & -20.9 \\
\hline All developing countries & -2.7 & -2.2 & -2.2 & 2.0 \\
\hline E. Europe and Central Asia & -2.3 & -3.1 & -3.5 & -0.3 \\
\hline China & -1.7 & -1.9 & -2.0 & -0.5 \\
\hline Other Southeast Asia & -1.6 & -1.9 & -2.0 & 3.1 \\
\hline India & -3.6 & -3.9 & -4.1 & -4.5 \\
\hline Other South Asia & -2.1 & -2.5 & -2.7 & 1.8 \\
\hline Middle East \& Nth Africa & -2.7 & -4.5 & -5.2 & 0.6 \\
\hline Sub-Saharan Africa & -7.2 & 10.0 & 9.0 & 41.6 \\
\hline Latin American \& Carib. & -1.7 & -3.4 & -3.7 & 5.3 \\
\hline World & -2.7 & -2.9 & -2.9 & -4.6 \\
\hline
\end{tabular}

Source: Anderson, Valenzuela and Jackson (2006) 
Figure 1: Welfare gain from cotton tariff and subsidy reform as a percent of GDP, as a multiple of the share for the world as a whole

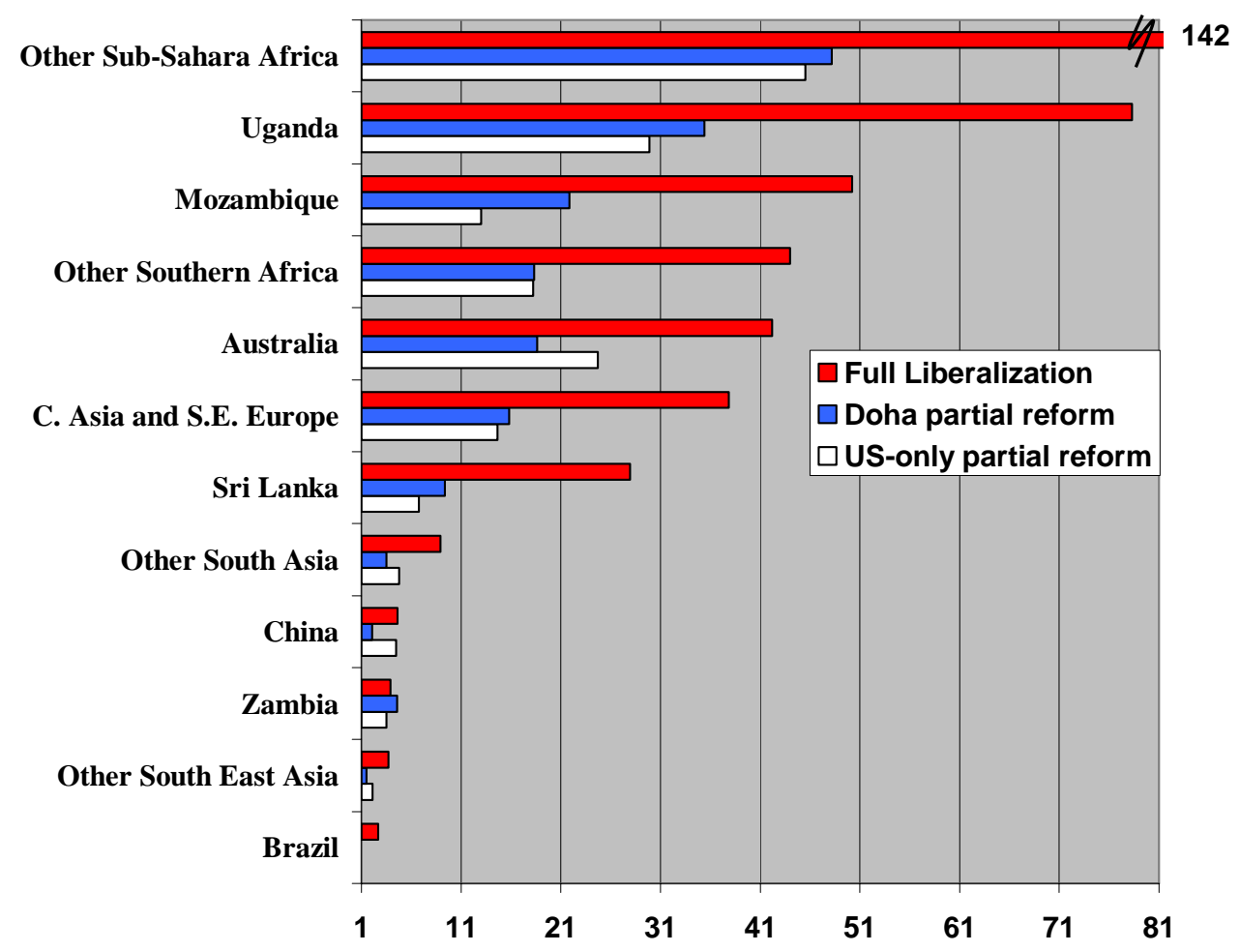

Source: Authors’ GTAP model simulation results 
Figure 2: Percentage change in cotton farm income from reform of cotton tariffs and subsidies, as a multiple of the percentage change for developing countries as a whole

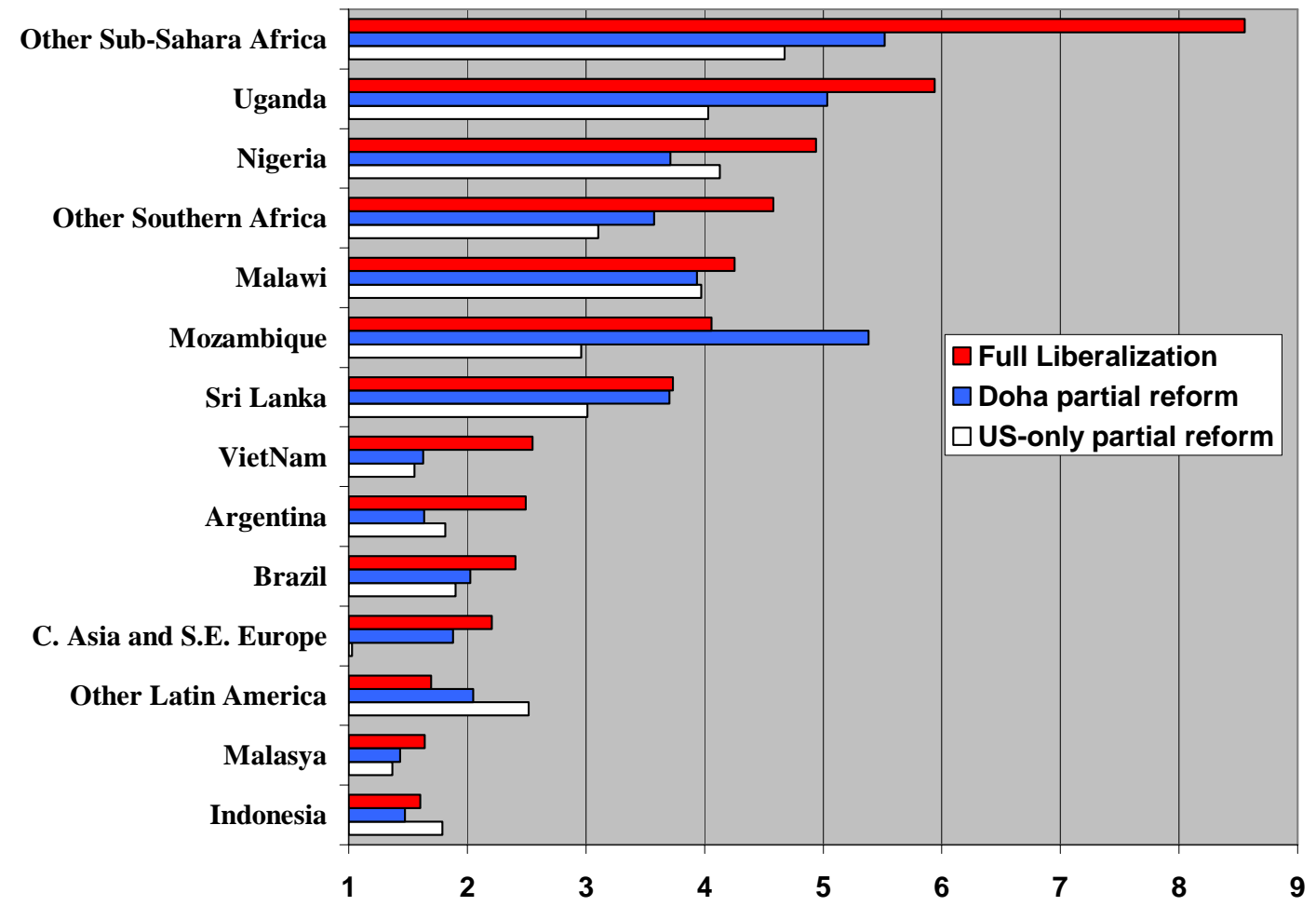

Source: Authors’ GTAP model simulation results 
Figure 3: Welfare change from the combination of cotton tariff and subsidy reform and post-2001 GM cotton adoption, as a percent of GDP, as a multiple of the percentage change for the world as a whole

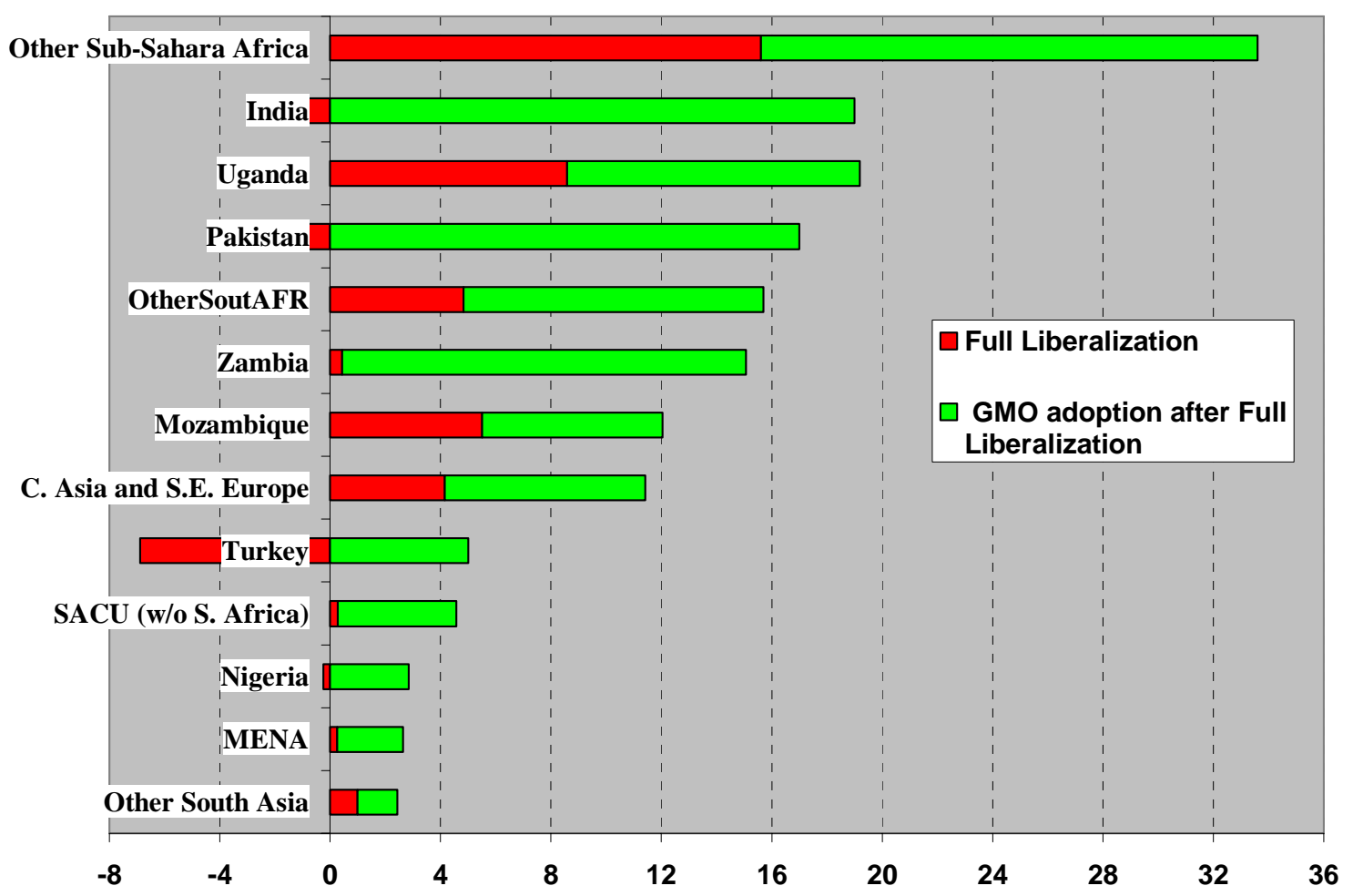

Source: Authors’ GTAP model simulation results 
Appendix Table A1: Volume of cotton ${ }^{\mathrm{a}}$ production, yield, trade and utilization, 2005-06

\begin{tabular}{|c|c|c|c|c|c|c|c|c|c|}
\hline & $\begin{array}{c}\text { Output } \\
\text { (Kt) }\end{array}$ & $\begin{array}{c}\text { Change ir } \\
\text { stocks } \\
(\mathrm{Kt})\end{array}$ & $\begin{array}{c}\text { Exports } \\
(\mathrm{Kt})\end{array}$ & $\begin{array}{c}\text { Imports } \\
(\mathrm{Kt})\end{array}$ & $\begin{array}{c}\text { Utilization } \\
(\mathrm{Kt})\end{array}$ & $\begin{array}{c}\text { Share of } \\
\text { supply } \\
\text { exported } \\
(\%)\end{array}$ & $\begin{array}{l}\text { National } \\
\text { share of } \\
\text { global } \\
\text { output(\%) }\end{array}$ & $\begin{array}{l}\text { National } \\
\text { share of } \\
\text { global } \\
\text { exports } \\
(\%)\end{array}$ & $\begin{array}{c}\text { Yield per } \\
\text { ha, \% of } \\
\text { global } \\
\text { average }\end{array}$ \\
\hline China & 5819 & 9 & 10 & 2800 & 8600 & 0 & 23.5 & 0.1 & 163 \\
\hline United States & 4735 & 408 & 3039 & 7 & 1296 & 70 & 19.1 & 37.5 & 122 \\
\hline India & 4250 & 550 & 225 & 125 & 3600 & 6 & 17.1 & 2.8 & 63 \\
\hline Pakistan & 2308 & 42 & 100 & 250 & 2415 & 4 & 9.3 & 1.2 & 103 \\
\hline Brazil & 1191 & -85 & 425 & 50 & 900 & 33 & 4.8 & 5.2 & 161 \\
\hline Uzbekistan & 1100 & 14 & 837 & 1 & 250 & 77 & 4.4 & 10.3 & 110 \\
\hline Turkey & 805 & 0 & 25 & 770 & 1550 & 3 & 3.2 & 0.3 & 181 \\
\hline Australia & 496 & -97 & 582 & & 11 & 98 & 2.0 & 7.2 & 258 \\
\hline Greece & 358 & 6 & 258 & 5 & 100 & 73 & 1.4 & 3.2 & 144 \\
\hline Syria & 298 & -9 & 150 & & 158 & 49 & 1.2 & 1.9 & 192 \\
\hline Egypt & 263 & -8 & 125 & 75 & 220 & 46 & 1.1 & 1.5 & 137 \\
\hline Burkina Faso & 254 & -14 & 264 & & 4 & 99 & 1.0 & 3.3 & 64 \\
\hline Mali & 250 & -1 & 247 & & 4 & 98 & 1.0 & 3.0 & 68 \\
\hline Turkmenistan & 219 & 6 & 114 & & 100 & 54 & 0.9 & 1.4 & 52 \\
\hline Tajikistan & 162 & 6 & 132 & & 25 & 85 & 0.7 & 1.6 & 80 \\
\hline Argentina & 155 & -5 & 50 & 20 & 130 & 31 & 0.6 & 0.6 & 63 \\
\hline Mexico & 152 & -33 & 45 & 287 & 428 & 24 & 0.6 & 0.6 & 169 \\
\hline Kazakhstan & 147 & 5 & 134 & 5 & 12 & 94 & 0.6 & 1.7 & 99 \\
\hline Benin & 140 & -49 & 186 & & 3 & 98 & 0.6 & 2.3 & 67 \\
\hline Côte d'Ivoire & 124 & 11 & 103 & & 10 & 91 & 0.5 & 1.3 & 62 \\
\hline Iran & 120 & 0 & 10 & 10 & 120 & 8 & 0.5 & 0.1 & 114 \\
\hline Cameroon & 112 & -78 & 57 & 1 & 132 & 30 & 0.5 & 0.7 & 69 \\
\hline Spain & 110 & 0 & 63 & 15 & 62 & 57 & 0.4 & 0.8 & 178 \\
\hline Sudan & 96 & 0 & 92 & & 4 & 96 & 0.4 & 1.1 & 67 \\
\hline Tanzania & 96 & -24 & 104 & & 16 & 87 & 0.4 & 1.3 & 31 \\
\hline Paraguay & 90 & 42 & 43 & & 5 & 90 & 0.4 & 0.5 & 49 \\
\hline Nigeria & 87 & 2 & 30 & 15 & 70 & 35 & 0.4 & 0.4 & 33 \\
\hline Zambia & 76 & 0 & 55 & & 20 & 72 & 0.3 & 0.7 & 39 \\
\hline Chad & 72 & -5 & 77 & & 1 & 100 & 0.3 & 0.9 & 33 \\
\hline Zimbabwe & 72 & -13 & 58 & & 26 & 68 & 0.3 & 0.7 & 36 \\
\hline Peru & 70 & 1 & 2 & 23 & 90 & 3 & 0.3 & 0.0 & 118 \\
\hline Togo & 70 & -9 & 79 & & 0 & 100 & 0.3 & 1.0 & 54 \\
\hline Myanmar & 59 & 0 & 11 & & 47 & 19 & 0.2 & 0.1 & 29 \\
\hline Colombia & 55 & 21 & & 78 & 111 & 0 & 0.2 & 0.0 & 109 \\
\hline Azerbaijan & 55 & 5 & 41 & & 8 & 82 & 0.2 & 0.5 & 71 \\
\hline Kyrgyzstan & 38 & 0 & 39 & 3 & 3 & 103 & 0.2 & 0.5 & 121 \\
\hline Uganda & 37 & -5 & 38 & & 4 & 90 & 0.1 & 0.5 & 52 \\
\hline Mozambique & 25 & -3 & 26 & & 2 & 93 & 0.1 & 0.3 & 16 \\
\hline Ethiopia & 22 & 0 & 2 & & 20 & 9 & 0.1 & 0.0 & 38 \\
\hline South Africa & 21 & 0 & & 39 & 60 & 0 & 0.1 & 0.0 & 73 \\
\hline
\end{tabular}

Source: ICAC (2005).

${ }^{a}$ Cotton, refers to ginned lint or raw cotton. It does not include seed cotton, linters, cotton mill waste, or cotton fibers subjected to any processing other than separation of lint from seed by the gin. Annual data are for the cotton year beginning 1 August. ${ }^{b}$ Supply is output plus change in stocks. 
Appendix Table A2: Dependence of cotton-producing developing countries on cotton export earnings, average 2000-02

\begin{tabular}{|c|c|c|c|c|c|}
\hline & $\begin{array}{c}\text { Share of } \\
\text { total } \\
\text { merchandise } \\
\text { export } \\
\text { revenue } \\
\text { from cotton } \\
(\%)\end{array}$ & $\begin{array}{l}\text { Value of } \\
\text { cotton } \\
\text { exports } \\
\text { (US\$m) }\end{array}$ & $\begin{array}{l}\text { National } \\
\text { share of } \\
\text { global } \\
\text { value of } \\
\text { cotton } \\
\text { exports } \\
\text { (\%) }\end{array}$ & $\begin{array}{l}\text { Cumulative } \\
\text { share of } \\
\text { global } \\
\text { value of } \\
\text { cotton } \\
\text { exports } \\
(\%)\end{array}$ & $\begin{array}{c}\text { Per } \\
\text { capita } \\
\text { income } \\
\text { (US\$) }\end{array}$ \\
\hline Benin & 46.8 & 131 & 1.9 & 1.9 & 380 \\
\hline Burkina Faso & 37.2 & 94 & 1.4 & 3.3 & 250 \\
\hline Chad & 32.9 & 59 & 0.9 & 4.2 & 210 \\
\hline Uzbekistan & 23.8 & 747 & 11.1 & 15.3 & 310 \\
\hline Mali & 22.4 & 161 & 2.4 & 17.7 & 240 \\
\hline Tajikistan & 12.3 & 89 & 1.3 & 19.0 & 180 \\
\hline Togo & 9.1 & 35 & 0.5 & 19.5 & 270 \\
\hline Turkmenistan & 7.6 & 201 & 3.0 & 22.5 & 1120 \\
\hline Kyrgyzstan & 6.7 & 33 & 0.5 & 23.0 & 290 \\
\hline Zimbabwe & 6.3 & 133 & 2.0 & 25.0 & $<730$ \\
\hline Guinea-Bissau & 5.0 & 3 & 0.0 & 25.0 & 130 \\
\hline Paraguay & 4.9 & 58 & 0.9 & 25.9 & 1170 \\
\hline Cameroon & 4.6 & 87 & 1.3 & 27.2 & 550 \\
\hline Tanzania & 4.0 & 31 & 0.5 & 27.6 & 290 \\
\hline Syria & 3.9 & 221 & 3.3 & 30.9 & 1130 \\
\hline Central African Rep. & 3.8 & 6 & 0.1 & 31.0 & 250 \\
\hline Egypt & 3.2 & 216 & 3.2 & 34.2 & 1470 \\
\hline Côte d'Ivoire & 3.2 & 137 & 2.0 & 36.2 & 620 \\
\hline Sudan & 2.9 & 50 & 0.7 & 37.0 & 370 \\
\hline Greece & 2.6 & 276 & 4.1 & 41.0 & 11660 \\
\hline Mozambique & 2.1 & 14 & 0.2 & 41.3 & 200 \\
\hline Uganda & 1.7 & 8 & 0.1 & 41.4 & 240 \\
\hline Australia & 1.5 & 943 & 14.0 & 55.4 & 19530 \\
\hline Malawi & 1.2 & 5 & 0.1 & 55.4 & 160 \\
\hline Senegal & 1.1 & 9 & 0.1 & 55.6 & 470 \\
\hline Kazakhstan & 0.9 & 85 & 1.3 & 56.8 & 1520 \\
\hline Pakistan & 0.9 & 85 & 1.3 & 58.1 & 420 \\
\hline Zambia & 0.8 & 9 & 0.1 & 58.2 & 340 \\
\hline Ethiopia & 0.8 & 4 & 0.1 & 58.3 & 100 \\
\hline Guinea & 0.5 & 3 & 0.0 & 58.3 & 410 \\
\hline Bolivia & 0.4 & 5 & 0.1 & 58.4 & 900 \\
\hline Gambia & 0.4 & 0 & 0.0 & 58.4 & 270 \\
\hline Ghana & 0.3 & 5 & 0.1 & 58.5 & 270 \\
\hline United States & 0.3 & 2121 & 31.5 & 90.1 & 35400 \\
\hline Azerbaijan & 0.3 & 6 & 0.1 & 90.2 & 710 \\
\hline WORLD & 0.1 & 6656 & 100.0 & 100.0 & 5510 \\
\hline
\end{tabular}

Source: FAOSTAT database at www.fao.org, except for final column which is from the World Bank’s World Development Indicators 2004 for the year 2002. 
Appendix Table A3: Cotton subsidies and import tariffs in 2001, and average applied tariffs on textile and clothing imports in $2005^{\mathrm{a}}$

\begin{tabular}{|c|c|c|c|c|c|c|}
\hline & \multicolumn{2}{|c|}{$\begin{array}{l}\text { Cotton production } \\
\text { subsidies: }\end{array}$} & \multirow{2}{*}{$\begin{array}{c}\text { Cotton } \\
\text { export } \\
\text { subsidies } \\
(\%)\end{array}$} & \multirow{2}{*}{$\begin{array}{c}\text { Cotton } \\
\text { import } \\
\text { tariffs } \\
(\%) \\
\end{array}$} & \multirow{2}{*}{$\begin{array}{c}\text { Textile } \\
\text { import } \\
\text { tariffs } \\
(\%) \\
\end{array}$} & \multirow{2}{*}{$\begin{array}{c}\text { Clothing } \\
\text { import } \\
\text { tariffs } \\
(\%) \\
\end{array}$} \\
\hline & US\$m & $\%$ & & & & \\
\hline High-income countries & 3461 & 33.8 & 0.0 & 0.2 & 6.3 & 8.6 \\
\hline Australia & 27 & 2.2 & 0 & 0.0 & 11.6 & 22.0 \\
\hline United States & 2969 & 40.2 & 0 & 0.6 & 7.3 & 9.4 \\
\hline Canada & 2 & 7.1 & 0 & 0.0 & 5.8 & 14.0 \\
\hline EFTA & 17 & 26.6 & 0 & 0.0 & 1.2 & 1.1 \\
\hline EU25 & 430 & 39.3 & 0 & 0.0 & 6.4 & 7.9 \\
\hline Japan & 12 & 3.7 & 0 & 0.0 & 6.4 & 9.2 \\
\hline Korea \& Taiwan & 1 & 1.5 & 0 & 0.7 & 8.6 & 12.2 \\
\hline Hong Kong \& Singapore & 0 & 0.0 & 0 & 0.0 & 0.0 & 0.0 \\
\hline Developing countries & 450 & 1.5 & 0.4 & 2.6 & 11.2 & 18.4 \\
\hline E. Europe \&Central Asia & 153 & 2.3 & 0 & 0.1 & 8.8 & 16.6 \\
\hline Russia & 27 & 14.8 & 0 & 0.2 & 9.5 & 18.7 \\
\hline Turkey & 115 & 3.9 & 0 & 0.0 & 13.3 & 19.9 \\
\hline Other E. Europe \& CA & 10 & 0.3 & 0 & 0.4 & 7.1 & 13.2 \\
\hline East Asia and Pacific & 0 & 0.0 & 0.0 & 2.0 & 9.7 & 15.5 \\
\hline China & 0 & 0.0 & 0 & 2.8 & 8.9 & 15.7 \\
\hline Indonesia & 0 & 0.0 & 0 & 0.2 & 8.3 & 12.5 \\
\hline Malaysia & 0 & 0.0 & 0 & 0.0 & 11.7 & 15.0 \\
\hline Philippines & 0 & 0.0 & 0 & 1.1 & 6.0 & 12.8 \\
\hline Thailand & 0 & 0.0 & 0 & 4.6 & 17.0 & 26.0 \\
\hline Viet Nam & 0 & 0.0 & 0 & 0.0 & 30.4 & 39.1 \\
\hline Other SE Asia Pacific & 0 & 0.0 & 0 & 2.4 & 3.4 & 3.1 \\
\hline South Asia & 235 & 2.9 & 0.0 & 3.8 & 20.8 & 20.0 \\
\hline Bangladesh & 0 & 0.0 & 0 & 0.9 & 29.5 & 36.6 \\
\hline India & 235 & 4.4 & 0 & 7.0 & 26.2 & 18.9 \\
\hline Pakistan & 0 & 0.0 & 0 & 0.2 & 1.2 & 8.0 \\
\hline Sri Lanka & 0 & 0.0 & 0 & 2.3 & 14.9 & 19.0 \\
\hline Other South Asia & 0 & 0.0 & 0 & 0.0 & 8.2 & 8.7 \\
\hline Middle East \& N. Africa & 26 & 0.9 & 2.4 & 6.1 & 16.2 & 21.4 \\
\hline Sub-Saharan Africa & 1 & 0.1 & 0 & 6.3 & 10.6 & 18.5 \\
\hline South Africa & 0 & 0.0 & 0 & 10.3 & 19.2 & 31.4 \\
\hline Other SACU & 0 & 0.0 & 0 & 0.4 & 12.7 & 7.4 \\
\hline Malawi & 0 & 0.0 & 0 & 2.1 & 19.9 & 18.7 \\
\hline Mozambique & 1 & 5.3 & 0 & 0.1 & 16.6 & 22.4 \\
\hline Zambia & 0 & 0.0 & 0 & 3.0 & 7.7 & 28.9 \\
\hline Other Southern Africa & 0 & 0.0 & 0 & 6.1 & 10.1 & 14.6 \\
\hline Nigeria & 0 & 0.0 & 0 & 1.4 & 30.1 & 36.0 \\
\hline Uganda & 0 & 0.0 & 0 & 0.6 & 22.6 & 28.9 \\
\hline Other Sub-Saharan Africa & 0 & 0.0 & 0 & 0.0 & 0.8 & 8.4 \\
\hline Latin America and Car. & 36 & 1.5 & 0.0 & 4.1 & 10.5 & 17.2 \\
\hline Argentina & 2 & 0.6 & 0 & 1.4 & 16.2 & 15.4 \\
\hline Brazil & 9 & 1.3 & 0 & 3.8 & 11.7 & 14.8 \\
\hline Mexico & 25 & 4.5 & 0 & 0.8 & 5.2 & 10.5 \\
\hline Other Latin Amer \& Car. & 0 & 0.0 & 0 & 9.9 & 13.5 & 20.8 \\
\hline
\end{tabular}


${ }^{a}$ GTAP database Version 6.05, with tariffs updated to 2005 following phase-out of textile and clothing quotas, and assuming a cotton output subsidy in the US of 40 percent in 2001.

Source: Update of GTAP database Version 6.05 at www.gtap.org 
Appendix Table A4: Value of textile production with and without protection, ${ }^{\text {a }}$ by region, 2001

\begin{tabular}{|c|c|c|c|c|}
\hline \multirow[b]{2}{*}{ Region $^{\mathrm{b}}$} & \multicolumn{2}{|c|}{$\begin{array}{l}\text { Region's share of global } \\
\text { textile production }\end{array}$} & \multicolumn{2}{|c|}{$\begin{array}{c}\text { Share of textiles in value of } \\
\text { region's total merchandise } \\
\text { production }\end{array}$} \\
\hline & $\begin{array}{c}\text { Under } \\
\text { protection }\end{array}$ & $\begin{array}{l}\text { Under } \\
\text { free trade }\end{array}$ & $\begin{array}{c}\text { Under } \\
\text { protection }\end{array}$ & $\begin{array}{l}\text { Under } \\
\text { free trade }\end{array}$ \\
\hline China & 24.5 & 26.0 & 8.7 & 9.2 \\
\hline United States & 17.3 & 15.6 & 2.5 & 2.3 \\
\hline EU25 & 14.8 & 14.0 & 2.0 & 1.9 \\
\hline Korea \& Taiwan & 5.7 & 7.3 & 5.6 & 7.1 \\
\hline Japan & 5.5 & 6.0 & 1.6 & 1.8 \\
\hline India & 4.5 & 4.5 & 7.5 & 7.5 \\
\hline Other Eastern Europe \& CA & 4.5 & 4.0 & 4.6 & 4.1 \\
\hline Mexico & 2.5 & 2.1 & 3.5 & 3.0 \\
\hline Other Latin Amer \& Carib & 2.3 & 2.0 & 3.8 & 3.4 \\
\hline Middle East \& Nth Africa & 2.0 & 1.6 & 2.2 & 1.8 \\
\hline Indonesia & 1.8 & 2.1 & 7.6 & 8.6 \\
\hline Pakistan & 1.8 & 1.9 & 25.2 & 26.5 \\
\hline Turkey & 1.5 & 1.5 & 9.5 & 9.1 \\
\hline Brazil & 1.5 & 1.4 & 3.0 & 2.9 \\
\hline Thailand & 1.4 & 1.6 & 7.1 & 7.8 \\
\hline Hong Kong \& Singapore & 1.3 & 1.9 & 6.1 & 7.5 \\
\hline Other SE Asia \& Pacific & 1.1 & 1.2 & 8.4 & 8.9 \\
\hline Canada & 1.0 & 0.9 & 1.6 & 1.3 \\
\hline Bangladesh & 0.9 & 0.8 & 14.7 & 12.9 \\
\hline Malaysia & 0.5 & 0.6 & 2.5 & 3.1 \\
\hline South Africa & 0.4 & 0.4 & 3.0 & 2.6 \\
\hline Australia & 0.4 & 0.3 & 1.4 & 1.2 \\
\hline Argentina & 0.4 & 0.3 & 2.0 & 1.8 \\
\hline Philippines & 0.3 & 0.4 & 2.7 & 3.2 \\
\hline Russia & 0.3 & 0.3 & 0.8 & 0.8 \\
\hline EFTA & 0.3 & 0.3 & 0.9 & 0.8 \\
\hline Other Southern Africa & 0.3 & 0.2 & 4.7 & 4.0 \\
\hline Other Sub-Saharan Africa & 0.3 & 0.3 & 2.2 & 2.1 \\
\hline Sri Lanka & 0.2 & 0.2 & 10.8 & 10.3 \\
\hline Other South Asia & 0.2 & 0.2 & 8.8 & 8.6 \\
\hline
\end{tabular}

a "Without protection" refers to what production would be without subsidies and tariffs in the cotton, textile and clothing markets globally, as generated by the GTAP model

b Same list of countries as in Appendix Table A3 and sorted according to region's share of global textile production in 2001. Regions with less than 1 percent share of the global market are not shown. They are Malawi, Mozambique, Nigeria, Other SACU, Singapore, Uganda, Viet Nam, and Zambia.

Source: GTAP database 6.05 and authors’ GTAP model simulation results 
Appendix Table A5: Bilateral trade flows, cotton and other plant-based fibres, $2001^{\mathrm{a}}$

(US\$million)

\begin{tabular}{|c|c|c|c|c|c|c|c|c|c|c|c|c|c|}
\hline Importer: & $\begin{array}{l}\text { United } \\
\text { States }\end{array}$ & $\begin{array}{l}\text { Aust- } \\
\text { ralia }\end{array}$ & EU25 & $\begin{array}{c}\text { High- } \\
\text { income } \\
\text { East } \\
\text { Asia }\end{array}$ & China & $\begin{array}{c}\text { Other } \\
\text { East } \\
\text { Asia }\end{array}$ & $\begin{array}{l}\text { South } \\
\text { Asia }\end{array}$ & $\begin{array}{c}\text { Eastern } \\
\text { Europe/ } \\
\text { Central } \\
\text { Asia }\end{array}$ & $\begin{array}{c}\text { Middle } \\
\text { East/ } \\
\text { North } \\
\text { Africa }\end{array}$ & Mexico & $\begin{array}{c}\text { Other } \\
\text { Latin } \\
\text { America }\end{array}$ & $\begin{array}{c}\text { Sub- } \\
\text { Saharan } \\
\text { Africa }\end{array}$ & $\begin{array}{l}\text { WORLD } \\
\text { Exports }\end{array}$ \\
\hline United States & 0 & 0 & 109 & 670 & 110 & 559 & 547 & 292 & 23 & 488 & 172 & 1 & 3054 \\
\hline Australia & 0 & 0 & 64 & 285 & 28 & 414 & 149 & 0 & 6 & 0 & 3 & 3 & 954 \\
\hline EU25 & 5 & 0 & 422 & 13 & 92 & 12 & 38 & 148 & 29 & 0 & 5 & 2 & 779 \\
\hline High-income East Asia & 0 & 0 & 0 & 0 & 1 & 6 & 24 & 0 & 0 & 0 & 0 & 0 & 36 \\
\hline China & 0 & 0 & 12 & 39 & 0 & 11 & 1 & 1 & 0 & 0 & 0 & 0 & 65 \\
\hline Other East Asia & 4 & 0 & 8 & 5 & 9 & 2 & 4 & 0 & 0 & 0 & 0 & 0 & 38 \\
\hline South Asia & 3 & 2 & 29 & 22 & 18 & 40 & 84 & 11 & 8 & 0 & 5 & 5 & 230 \\
\hline E. Europe/Central Asia & 14 & 1 & 504 & 88 & 17 & 13 & 87 & 427 & 11 & 0 & 7 & 0 & 1179 \\
\hline Middle East/N. Africa & 13 & 0 & 165 & 25 & 19 & 41 & 121 & 54 & 31 & 0 & 9 & 3 & 489 \\
\hline Mexico & 2 & 0 & 5 & 8 & 1 & 3 & 0 & 0 & 0 & 0 & 8 & 0 & 29 \\
\hline Other Latin America & 8 & 0 & 58 & 13 & 4 & 42 & 75 & 17 & 2 & 4 & 82 & 5 & 315 \\
\hline Sub-Saharan Africa & 0 & 0 & 326 & 89 & 8 & 227 & 95 & 23 & 43 & 4 & 91 & 77 & 999 \\
\hline WORLD & 63 & 4 & 1705 & 1261 & 308 & 1399 & 1249 & 977 & 158 & 497 & 385 & 98 & \\
\hline
\end{tabular}

${ }^{\text {a }}$ GTAP database Version 6.05, with tariffs updated to 2005 following phase-out of textile and clothing quotas, and assuming a cotton output subsidy in the US of 40 percent in 2001. The inclusion in this table of other plant-based fibres such as flax is important only for a few developing countries such as Bangladesh.

Source: Update of GTAP database Version 6.05 at www.gtap.or 